\title{
Effects of Blackberry Messenger Usage on the Academic Activities of Agriculture Students in University Of Portharcourt
}

\author{
Ifeanyi-obi C.C, Olatunji S.O and Enyindah, F. \\ Department of Agricultural Economics and Extension, Faculty of Agriculture University of Port Harcourt.
}

\begin{abstract}
This study identified the effects of blackberry messenger usage on academic activities of agriculture students in the University of Port Harcourt. Eighty agriculture students were selected for the study using simple random sampling technique. Data was collected using Structured questionnaire and analyzed using descriptive statistics namely frequency, percentages and mean. The result shows that $59 \%$ were females and $78.2 \%$ fall between the age brackets of 21-30 years. Other social media used by the students include 2go (55.1\%), blackberry messenger (100\%), Facebook (89.7\%), Skype (84.6\%), Whatsapp (59.0\%), Twitter (33.3\%), LinkedIn (6.4\%), Youtube (20.5\%) and Google $+(26.5 \%)$. About $94.9 \%$ has access to internet through their blackberry device, $43.6 \%$ go online through their blackberry device very often while $30.8 \%$ spend $2-5$ hours on blackberry messenger on daily basis. The major activity performed by the agriculture students with their blackberry device is educational activities (44.9\%) while the major effects of blackberry messenger usage on academic activities of agriculture students were; it facilitates their research work $(x=3.4)$, facilitates networking with other agricultural students $(x=3.2)$, distracts them from carrying out academic assignments $(X$ $=2.5)$, constitutes distraction to private studies $(X=2.6)$ and participation during lectures $(X=2.5)$ It was recommended that excessive usage of blackberry messenger for recreational activities should be discouraged among students
\end{abstract}

Keywords: perceived effects, blackberry messenger, agriculture students, academic activities

\section{Introduction}

The advent of ICT in Agriculture aroused mixed feelings in the minds of stakeholders in the agricultural sector especially among farmers and some level of agricultural practitioners in many under developed and developing countries who see the use of these ICT devices as complex and unaffordable. Recently, the emergence of low cost mobile devices has made even farmers in the most remote villages become part of this global change. The ease of communication and information sourcing offered by these mobile devices make it attractive to many. In addition, the moderate cost of these mobile devices makes it an affordable venture for most farmers in the developing world. These devices are fast changing the face of agricultural activities from what it used to be. Many relevant and useful innovations are being introduced in the agricultural sector through the use of these devices. Ogunlesi (2012) identified agricultural sector as one of the sectors being transformed by mobile devices in Africa. According to him, mobiles phones by serving as platforms for sharing weather information, market prices, and micro-insurance schemes are allowing Africa's farmers to make better decisions, translating into higher-earning potentials. In the same vein, Donovan (2012) noted that mobile phones can help to increase income, improve the efficiency of markets, reduce transaction costs, and offer a great opportunity for innovative interventions, especially in service delivery in agricultural sector.

In addition, Christine (2011) noted that mobile communications technology has quickly become the world's most common way of transmitting voice, data, and services in the developing world. He further stated that mobile applications (m-apps) in general and mobile applications for agricultural and rural development (m-ARD apps) in particular hold significant potential for advancing development as they could provide the most affordable ways for millions of people to access information, markets, finance, and governance systems previously unavailable to them.

Communication in agricultural sector has experienced diverse problems in Nigeria. This has adversely affected the development of agricultural sector in the nation. With the advent of mobile phones, the problem of communication in the agricultural sector seem to experience some relief as the application of theses mobile phone devices in information sharing is gradually closing the communication gap among key players in the sector. The agricultural students are not left out in this as communication has always been an essential activity among students especially in this modern era (Enikuomehin, 2011; Ackerman, 2010; Haythornthwaite, 2005; Akindehin, 2005; Akindehin, 2004; Lasis, 2004). Students have always sought for better, easier and faster means to communicate with one another. The emergence of information and communication technology (ICT), especially social media tools like blackberry messenger, facebook etc seem to quench this thirst.

Blackberry messenger (BBM) is a proprietary internet based instant messenger application included on blackberry devices that allows messaging. A blackberry device can shot video, take photos, and play music, and 
perform online functions such as web browsing and emailing, they can also be use for making of calls, send and receive message, push email and instant message while maintaining a high level of security through on-device message encryption and are designed to function as personal digital assistants. It enables the owners to download and save other social network application like facebook, twitter, 2go, ebudy etc.

Blackberry accounts for $3 \%$ of mobile device sale worldwide in 2011, making its manufacturers the sixth popular device maker ( $25 \%$ of mobile device sale are smart phones).

As of September, 2012 there were eighty million subscribers worldwide to blackberry. Blackberry and its messenger are considered as the major smart phone brand (Wikipedia 2013). Recently, android phones can download and use the blackberry messenger after subscribing to the respective network. This has tremendously increased the numbers of blackberry messenger users.

It has been observed that the rate at which students in faculty of agriculture communicate with this Blackberry messenger is on the increase. Majority of agriculture students use blackberry messenger as the major means of communication with other students. This increase in the use of blackberry messenger by students has aroused concern in the minds of both lecturers and parents. This research therefore examined the effects of blackberry messenger usage on the academic activities of agricultural students in university of Port-Harcourt (UNIPORT). Specifically, the study examined the socio economic characteristics of agriculture students in the study area, identified the different uses of blackberry messenger among the agriculture students and assessed the effect of blackberry messenger usage on the academic activities of agric students in university of Port-Harcourt (UNIPORT).

\section{Methodology}

The study area is Faculty of Agriculture, University of Port-Harcourt. The population of the study comprises of all students in the faculty of agriculture. Random sampling technique was used to select 80 students for the study. Four students were randomly selected from each level of each of the four departments in the faculty giving a total of 80 students for the study. This was to ensure that all levels and department were represented in the study. Structured questionnaire was used to collect data from the agriculture students and was analyzed using descriptive statistics namely frequency, percentages and mean. Focused group discussion was also applied to get in depth knowledge from the students. Tables were used to present the result of the study. Of the eighty questionnaires shared for the study, only 78 was useful for the analysis. 4 Point-Likert type scale was used to measure the effects of blackberry messenger usage on academic activities of agriculture students. A midpoint of 2.50 was obtained and based on this, decision rule was that any mean score greater than or equal to 2.50 implies agreement with the statement, and any mean score less than 2.50 implies disagreement with the statement.

\section{Socio economics characteristics of Agricultural students \\ III. Result And Discussion}

Table 1 shows socio economic characteristics of respondents (agricultural students). It shows that majority $(59 \%)$ of respondents were females. This is an indication that the female has more number of blackberry users than their male counterpart. The Table went further to show the ages of students. From the result obtained, it was shown that $78.2 \%$ of respondents were between the ages of 21-30 years old. This shows that the information used in this study was mainly produced by students in this age bracket. Also, this category of people are youths whose one of the major characteristic is innovativeness. Bearing this in mind, it is worthy to note that given the right orientation and enlightenment, they could explore the uses of blackberry even to the extent of inventing new things from it. Furthermore, the Table shows the other social media tools used by agriculture students. Of the nine social media tools used to capture this, the agriculture students indicated that they use $2 \mathrm{go}$ (55.1\%), blackberry messenger (100\%), Facebook (89.7\%), Skype (84.6\%), Whatsapp (59.0\%), Twitter (33.3\%), Linkeld (6.4\%), Youtube (20.5\%) and google (26.5\%).

Table 1: Distribution of agriculture students according to their socio-economic characteristic.

\begin{tabular}{lcc}
\hline Variable & Frequency & Percentage \\
\hline Gender & & \\
Male & 32 & 41.0 \\
Female & 46 & 59.0 \\
Age & & 11.5 \\
$<20$ & 9 & 78.2 \\
$21-30$ & 61 & 10.3 \\
Above 30 & 8 & \\
Which of the social network site do you & & \\
have an account & & \\
2go & &
\end{tabular}


Yes

No

BB messenger

Yes

No

Face-book

Yes

No

Skype

Yes

No

Whatsapp

Yes

No

Twitter

Yes

No

Linkedin

Yes

No

YouTube

Yes

No

Google

Yes

No

Source: Field survey 2014
55.1

44.9

100.0

NIL

89.7

10.3

84.6

15.4

59.0

41.0

33.3

66.7

6.4

93.6

20.5

79.5

20.5

79.5

Time spent on and activities performed with blackberry messenger by agricultural students.

Table 2 shows that $94.9 \%$ has access to internet through their blackberry device. Also distribution of agriculture students by the frequency of use of blackberry messengers indicate that $43.6 \%$ goes online through their blackberry device very often. Furthermore, $30.8 \%$ of respondents spend 2-5 hours on blackberry messenger on daily basis. The major activity performed by the agriculture students with their blackberry device is educational activities $(44.9 \%)$.

The findings is in this section is a vivid evident that agriculture students spend relatively good proportion of their time on blackberry usage. Through the focused group discussion, it was gathered that the major educational activity carried out by the students with their blackberry is sourcing for information that will enable them do their assignments. Bearing in mind that majority of the students have access to internet in their blackberry, exposing them to other useful activities they could do with their blackberry can be beneficial to both students and the lecturers as this could launch the students into exploring other avenues of positively applying the use of blackberry messenger to their course of study.

Table 2: Distribution of agriculture student by activities performed with blackberry

\begin{tabular}{|c|c|c|}
\hline \multicolumn{3}{|c|}{$\begin{array}{l}\text { Do you have access to internet on your } \\
\text { blackberry device }\end{array}$} \\
\hline No & 4 & 5.1 \\
\hline \multicolumn{3}{|c|}{$\begin{array}{l}\text { How often do you go online through your } \\
\text { blackberry device }\end{array}$} \\
\hline Very often & 34 & 43.6 \\
\hline Often & 31 & 39.7 \\
\hline$<1$ hour & 14 & 17.9 \\
\hline 2-3hour & 24 & 30.8 \\
\hline 4-5hour & 24 & 30.8 \\
\hline
\end{tabular}




\begin{tabular}{|c|c|c|}
\hline $\begin{array}{l}\text { What is the ma } \\
\text { your blackberr }\end{array}$ & & \\
\hline Educational & 35 & 44.9 \\
\hline Sport and news & 24 & 30.9 \\
\hline Entertainment & 19 & 24.2 \\
\hline Other specify & Nil & Nil \\
\hline
\end{tabular}

\section{Source: Field survey 2014}

Effects of blackberry messenger usage on academic activities of agric student.

Table 3 shows the effect of blackberry messenger on students' academic activities. The agriculture students agree that blackberry messenger facilitates their research work $(M=3.4)$, facilitates networking with other agricultural students $(M=3.2)$, distracts them from carrying out academic assignments $(M=2.5)$, constitutes distraction to private studies $(\mathrm{M}=2.6)$ and participation during lectures $(\mathrm{M}=2.5)$ were the major effects of blackberry messenger usage on their academic activities.

The result reveals that blackberry phone usage impact both positively and negatively on the agriculture students. The students through the focused group discussion revealed that in using the blackberry messenger to source for information to carry out their assignment online, sometimes they get distracted and end up chatting with their friends instead of carrying out their assignment. This also happens during their private study time, the beeping sound of their blackberry phones lure them to pick up the phones and many a times end up chatting with friends instead of reading. of blackberry

It could be drawn from this that agriculture students are yet to discipline themselves in the proper use

Table 3: Distribution of agriculture students according to the effects of blackberry messenger usage on academic performance of students.

\begin{tabular}{|c|c|c|c|c|c|c|c|}
\hline $\mathbf{S} / \mathbf{N}$ & Statement & $\begin{array}{c}\text { Strongly } \\
\text { agree }\end{array}$ & Agree & Disagree & $\begin{array}{l}\text { Strongly } \\
\text { disagree }\end{array}$ & Mean X & Remark \\
\hline 1 & $\begin{array}{l}\text { BBM distracts me } \\
\text { from carrying out } \\
\text { academic assignments }\end{array}$ & $12(15.4)$ & $30(38.5)$ & $21(26.9)$ & $15(19.2)$ & 2.5 & Agree \\
\hline 2 & $\begin{array}{l}\text { It constitutes } \\
\text { distraction to my } \\
\text { private study }\end{array}$ & $13(16.7)$ & $33(42.3)$ & $19(24.4)$ & $13(16.7)$ & 2.6 & Agree \\
\hline 3 & $\begin{array}{lr}\text { BBM distracts my } \\
\text { concentration } \\
\text { participation and } \\
\text { lectures }\end{array}$ & $12(15.4)$ & $32(41.0)$ & $19(24.4)$ & $15(19.2)$ & 2.5 & Agree \\
\hline 4 & $\begin{array}{l}\text { It facilitates my } \\
\text { research work }\end{array}$ & $43(55.1)$ & $24(30.8)$ & $7(9.0)$ & $4(5.1)$ & 3.4 & Agree \\
\hline 5 & $\begin{array}{l}\text { BBM facilitates } \\
\text { networking with other } \\
\text { agricultural students }\end{array}$ & $32(41.0)$ & $36(46.2)$ & $7(9.0)$ & $3(3.8)$ & 3.2 & Agree \\
\hline 6 & $\begin{array}{lr}\text { BBM } & \text { aids } \\
\text { collaboration } & \text { with } \\
\text { other agricultural } \\
\text { students }\end{array}$ & $30(38.5)$ & $37(47.4)$ & $6(7.7)$ & $5(6.4)$ & 2.1 & Disagree \\
\hline 7 & $\begin{array}{l}\text { It increases access to } \\
\text { my lecturers }\end{array}$ & $11(14.1)$ & $8(10.3)$ & $35(44.9)$ & $24(30.8)$ & 2.1 & Disagree \\
\hline 8 & $\begin{array}{l}\text { It facilitates better } \\
\text { relationship with my } \\
\text { lecturers }\end{array}$ & $8(10.3)$ & $11(14.1)$ & $40(51.3)$ & $19(24.4)$ & 1.2 & Disagree \\
\hline
\end{tabular}

Source: Field survey 2014

Overall rating of effects of blackberry messenger usage on academic activities of agriculture students.

Table 4 shows the overall rating of effects of blackberry messenger on academic activities of agricultural students. Majority (79.5\%) of the students indicated that blackberry messenger affect their academic activities positively, while $20.5 \%$ indicated that blackberry messenger usage affects their academic activities negatively. 
Table 4 : Distribution of students according to overall rating of effect of blackberry messenger usage on academic activities of agriculture students.

\begin{tabular}{lcc}
\hline Variable & Frequency & Percent \\
\hline $\begin{array}{l}\text { Blackberry usage affect my academic } \\
\text { performance positively }\end{array}$ & 62 & 79.5 \\
$\begin{array}{l}\text { Blackberry usage affect my academic } \\
\text { performance negatively }\end{array}$ & 16 & 20.5 \\
\hline
\end{tabular}

\section{Source: Field survey 2014}

\section{Conclusion And Recommendations}

Based on the findings of this study, it is concluded that blackberry messenger usage affect academic activities of agriculture students positively. Although, blackberry messenger usage impact positively on the academic activities of students, some students misuse this innovation thereby resulting to negative effect on their academic performances.

Based on the findings of this study, it is revealed that further research on how to curtail the negative use of blackberry phones by students is needed. It is therefore recommended that this should be done in order to create more awareness on the negative effects of blackberry messenger usage on student's academic activities. This awareness could be created through organizing seminars or workshops for the Nigeria association of agricultural student (NAAS). Also, the school management can harness the positive uses of black berry messenger and use it to make teaching, training, networking and collaboration among students more effective.

\section{References}

[1]. Ackerman, P.L., Kanfer, R, Shapiro, S.W., \& Beier, M (2010). Cognitive Fatigue During Test. An Examination of Trit, time-on-test and Strategy Influences. Human performance. 23(5), 381-402.

[2]. Akindehin, F. (2004) Education As A Means Of Economic And Social Reconstruction. Journal of Curriculum And Instruction. 12(1), $1-8$.

[3]. Akindehin, F. (2005) Cotemporary Issues In School Science Teaching. The Place of Classroom Learning Activities. Osiele Journal Educational studies. 5,25-32.

[4]. Christine Z. Q., Siou C. K.,Andrew D. and Steve E. (2011). Mobile Applications for Agriculture and Rural Development. http://siteresources.worldbank.org/Informationandcommunicationandtechnologies/Resources/MobileApplications for ARD.pdf Retrieved Feb 23rd, 2014.

[5]. Donova Kevin (2012) Overview of ICT in agriculture: opportunities, access, and crosscuttingthemes.http://www.ictinagriculture.org/sites/ictinagriculture.org/files/final Module3.pdf . Retrieved $15^{\text {th }} \mathrm{Feb} 2014$

[6]. Enikuomehin O.A (2011). ICT, CGPA: Consequences Of Social Networks In An Internet Driven Learning Society. International Journal Of Computer Trends and Technology-Volume 2 Issue 2- 2011

[7]. Haythornthwaite, C. (2005). Social Networks and Internet Connectivity Effects Information, Communication \& Society (2). $125-147$.

[8]. Lasisi, J.A (2004). Internet has replaced Oral story platform. The Punch. June 14, 38.

[9]. Mayer, R.E. (2009). Information Processing Variable in learning to Solve problems. Review of Educational Research 45 (4). $525-541$.

[10]. Ogunlesi, T.(2012). Seven ways mobile phones have changed lives in Africa. http://edition.cnn.com/2012/09/13/world/africa/mobilephones-change-africa/ Retrived March $4^{\text {th }}, 2014$. 